\title{
Water Demand Forecast in the Baiyangdian Basin with the Extensive and Low-Carbon Economic Modes
}

\author{
T. L. Qin, D. H. Yan, G. Wang, and J. Yin \\ Water Resources Department, China Institute of Water Resources and Hydropower Research, Beijing 100038, China
}

Correspondence should be addressed to D. H. Yan; denghuay@gmail.com

Received 13 December 2013; Revised 28 April 2014; Accepted 5 May 2014; Published 5 June 2014

Academic Editor: Yuefei Huang

Copyright (C) 2014 T. L. Qin et al. This is an open access article distributed under the Creative Commons Attribution License, which permits unrestricted use, distribution, and reproduction in any medium, provided the original work is properly cited.

\begin{abstract}
The extensive and low-carbon economic modes were constructed on the basis of population, urbanization level, economic growth rate, industrial structure, industrial scale, and ecoenvironmental water requirement. The objective of this paper is to quantitatively analyze effects of these two economic modes on regional water demand. Productive and domestic water demands were both derived by their scale and quota. Ecological water calculation involves the water within stream, wetland, and cities and towns. Total water demand of the research region was obtained based on the above three aspects. The research method was applied in the Baiyangdian basin. Results showed that total water demand with the extensive economic mode would increase by 1.27 billion $\mathrm{m}^{3}, 1.53$ billion $\mathrm{m}^{3}$, and 2.16 billion $\mathrm{m}^{3}$ in 2015, 2020, and 2030, respectively, compared with that with low-carbon mode.
\end{abstract}

\section{Introduction}

Affected by climate change and economic-social development, water resource problems such as excess water, water shortage in quantity and quality, aggravation of hydroecological and hydroenvironmental system, disorder of hydrosedimentary system, low water efficiency, and unsustainable water resource management which has been discussed by Wang [1] have become more diverse and serious. These problems have led to water resource crisis and intensified the relationship between water supply and water demand.

Water demand forecast has gained more attention in water-deficient areas due to the increasing water requirement of rapid economic development. It is not only the basis of national economic and social development plans, water resource plans, and operation plans of hydraulic projects and water management, but also the equilibrium point between social-economic system and ecoenvironmental system, as discussed elsewhere [2,3]. Different economic development modes should be taken into consideration of the water demand forecast of different level years in the future for targets of economic and social development, energy conservation and pollution reduction, and water resources protection. It becomes a key technique for rational allocation of water resources towards the low-carbon development mode, rational deployment of water resources based on macroeconomic structure, and ecology-oriented reasonable deployment of water resources, as discussed elsewhere [4-7].

Research of water demand abroad began at the 1st evaluation of national water resources in USA in 1968. Water use structure in most developed countries such as EU and US has changed into sustainable mode steadily. Forecast method of water demand is becoming mature. Gistau et al. established pattern recognition model to forecast short-term domestic and industrial water demand [8, 9]. Zhou et al. applied time series method in the city of Melbourne to forecast daily urban water demand [10]. Mays established logarithmic and semilogarithmic regression model relating water demand and relative factors for the media-long term and applied it to Texas of USA [11]. Adamowski established peak daily water demand forecast modeling using artificial neural networks [12]. Yasar et al. forecast water demand of Adana city of Turkey using stepwise multiple nonlinear regression analysis model [13].

In China, water demand forecast began when the 1st evaluation of national water resources started in 1980. Zhong et al. constructed comprehensive prediction method based on the general formula, integrating advantages of some common methods [14]. Zhang et al. forecast domestic water demand of Beijing with multiple-linear regression model [15]. Lv et al. established practical dynamic model of urban water 
TABLE 1: Comparison of two factors of two economic modes.

\begin{tabular}{|c|c|c|}
\hline Item & Extensive economic mode & Low-carbon economic mode \\
\hline Economic growth rate & Rate of 2010 & Optimal economic growth rate \\
\hline Industrial structure & Structure of 2010 & Optimal structure \\
\hline Water use quota & Quota of 2010 & $\begin{array}{l}\text { Decreasing water quota in accordance with Twelfth Five-Year Plan of } \\
\text { Water Conservancy }\end{array}$ \\
\hline Water use structure & Status of 2010 & $\begin{array}{l}\text { Adjusting the structure of water use in accordance with the optimal } \\
\text { industrial one }\end{array}$ \\
\hline Natural ecological water demand & No consideration & $\begin{array}{l}\text { Considering reasonable ecological flow requirement within the stream } \\
\text { and wetland ecological water demand }\end{array}$ \\
\hline
\end{tabular}

consumption [16]. Zhang et al. established projection pursuit model of water demand prediction based on IEA which solved high dimension, nonlinear, nonnormal problems, and so forth [17].

Research advances above show that the developments of mathematical methods and computer simulation technique promote water demand forecast methods. There are three types of forecast methods, including trend analysis, time series, and numerical simulation. Some methods are in common use at present, such as pattern recognition model, regression model, comprehensive prediction method based on the general formula, practical dynamic model to predict water consumption, grey system method, projection pursuit means, and artificial neural networks [18-24].

These above means are produced and applied to water demand forecast in different basins. However, they lack effect analysis of low-carbon economic development mode on water consumption and comparison of water demand forecast between varied economic modes. Economic development mode of China is being changed into green, lowcarbon, and sustainable mode so that water demand forecast has to consider its effect on regions and different water users.

The purpose of this paper is to analyze effect of extensive and low-carbon economic development mode on total regional water demand and different water users. In the former mode, many kinds of resources are consumed to keep rapid economic growth but there exists unreasonable structure of industries and water use, resulting in the occupancy of ecological water demand, excessive water consumption by economic-social system, large energy consumption, and carbon emission. The content of carbon dioxide in the atmosphere could increase, which could intensify regional climate change. In the latter mode, total water consumption, energy consumption, and carbon emissions are all reduced by decreasing quota of water use and optimizing the structure of industries, water use, and energy consumption and considering reasonable water demand of ecosystems. This mode can promote the construction of low-carbon society and mitigate climate change. Key factors of the two modes are detailed in Table 1 .

\section{Materials and Methods}

2.1. Study Area. The Baiyangdian basin is located in the middle of the North China Plain and Haihe River basin.
Its geographic coordinates are roughly E113 ${ }^{\circ} 40^{\prime} \sim \mathrm{E}_{11}{ }^{\circ} 48^{\prime}$ and $\mathrm{N} 38^{\circ} 10^{\prime} \sim \mathrm{N} 40^{\circ} 03^{\prime}$. The basin covers an area of about $34878.25 \mathrm{~km}^{2}$

Rivers stretch through Shanxi province, Hebei province, and Beijing municipality. The inflow is mainly from upstream rivers including Juma River, Zhong-yishui River, Baigou River, Puhe River, Caohe River, Qingshui River, Tanghe River, Zhulong River, and Cihe River. Through Zaolinzhuang conjunction, these rivers flow into Zhaowang New Channel and then converge into Dongdian of Baiyangdian wetland. After that they flow into Xiaobai River in the lower reach and then flows into Haihe River through Duliujian River, as discussed by Bai and Ning [25], shown in Figure 1.

Annual average precipitation volume of the basin is 1.902 billion $\mathrm{m}^{3}, 70 \%-80 \%$ of which falls in the flood season from June to September, as discussed by Wang and $\mathrm{Xu}$ [27].

Total amount of water consumption was about 4.65 billion $\mathrm{m}^{3}$ in 2010, of which productive, domestic, and ecoenvironmental water consumption were, respectively, 4.05 billion $\mathrm{m}^{3}, 0.47$ billion $\mathrm{m}^{3}$, and 0.13 billion $\mathrm{m}^{3}$. Gross domestic product (GDP) was about 460.26 billion RMB in the same year, of which the growth rate was greater than $10 \%$. Economic development and population growth brought about high water consumption. There are series of ecoenvironmental problems in the basin, including water resource shortage, groundwater overexploitation, ecological water being taken possession, occupied ecological land, and deteriorated water quality.

2.2. Basic Data. Water demand forecast involves six types of data, consisting of socioeconomic development, water resource, scale and quota of water consumption, water use indexes, and hydrological observation data. Details and sources are listed in Table 2.

2.3. Forest Method. Water demand forecast of research region includes productive, domestic, and ecological part. Details are listed in Table 3. The two former parts and ecological demand for cities and towns were derived by multiplying scale by quota. The technical framework of this paper is detailed in Figure 2.

In respect of production water demand, based on the historical data of GDP, optimal economic growth rate and GDP were obtained with Cobb-Douglas production function 


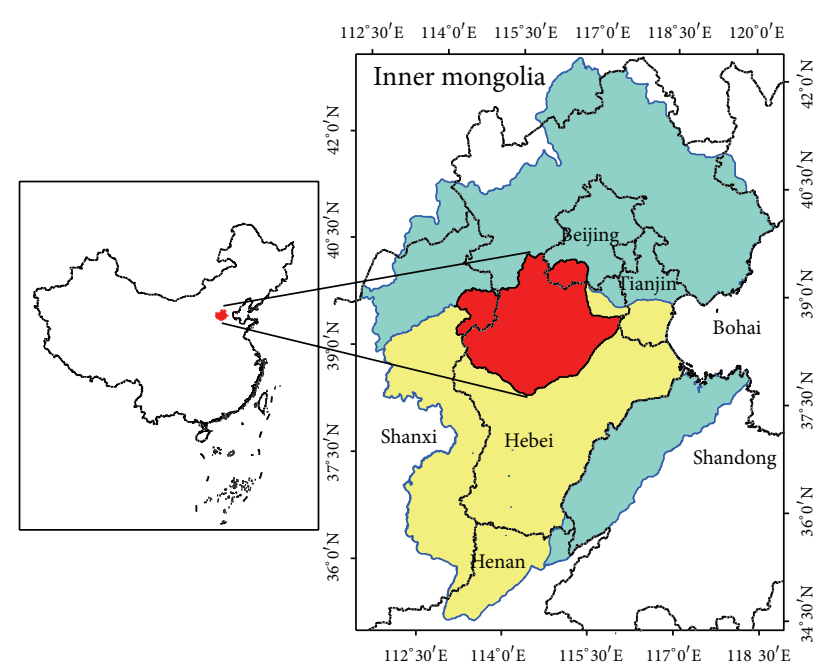

$-\ldots$ National boundary
$\square$ Province boundary
$\square$ Study area boundary
Daqinghe River Diandong plain Haihe River basin

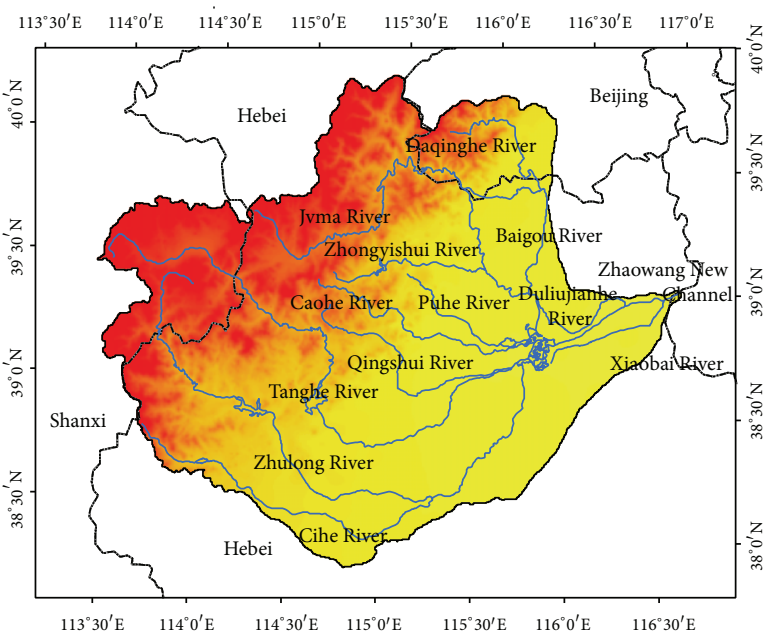

Basin boundary
Rivers
$\square$ PEM High: 2626
Povince boundary 1

(b)

(a)

FIGURE 1: (a) Location of research area; (b) river net and digital elevation distribution [26].

TABLE 2: Basic data of water demand forecast.

\begin{tabular}{|c|c|c|}
\hline Data type & Details & Major source \\
\hline Socioeconomic development & $\begin{array}{l}\text { Population, urbanization level, GDP, industrial } \\
\text { structure, and investment in fixed assets }\end{array}$ & $\begin{array}{l}\text { Statistical yearbook of Beijing municipality, Hebei } \\
\text { province, and Shanxi province during 2005-2010 }\end{array}$ \\
\hline Water resource amount & Water consumption & $\begin{array}{l}\text { Water resources bulletin and attached list during } \\
\text { 2001-2010 }\end{array}$ \\
\hline Water-consumption scale & $\begin{array}{l}\text { Irrigation area, forestland area, fish pond area, } \\
\text { the number of livestock and poultry, and green } \\
\text { land area of cities }\end{array}$ & $\begin{array}{l}\text { Statistical yearbook of Beijing municipality, Hebei } \\
\text { province, and Shanxi province during 2005-2010 }\end{array}$ \\
\hline Water-consumption quota & $\begin{array}{l}\text { Irrigation quota, water-consumption quota of } \\
\text { animal husbandry and fishery, and } \\
\text { water-consumption quota of secondary and } \\
\text { tertiary industry }\end{array}$ & $\begin{array}{l}\text { Water conservancy yearbook during } 2005-2010 \text { and } \\
\text { Twelfth Five-Year Plan of Beijing municipality, Hebei } \\
\text { province, and Shanxi province }\end{array}$ \\
\hline Water-consumption index & Water efficiency of irrigation and cannels & $\begin{array}{l}\text { Water conservancy yearbook of Beijing municipality, } \\
\text { Hebei province, and Shanxi province during 2005-2010 }\end{array}$ \\
\hline Hydrological data & Daily flow discharge & Hydrological yearbook during 1956-2000 \\
\hline
\end{tabular}

TABLE 3: Major departments of productive, domestic, and ecological water users.

\begin{tabular}{ll}
\hline Water users & Major divisions \\
\hline $\begin{array}{l}\text { Productive users } \\
\text { Primary industry } \\
\text { Secondary industry }\end{array}$ & $\begin{array}{l}\text { Agriculture, forestry, animal husbandry, and fishery } \\
\text { General industry and construction } \\
\text { Tertiary industry }\end{array}$ \\
$\begin{array}{l}\text { Other industries except for the primary and secondary industry, including service, banking, insurance, } \\
\text { transportation, medical treatment, and education }\end{array}$ \\
Domestic users & Residents of cities and villages \\
Ecological users & Natural and artificial ecosystem \\
\hline
\end{tabular}




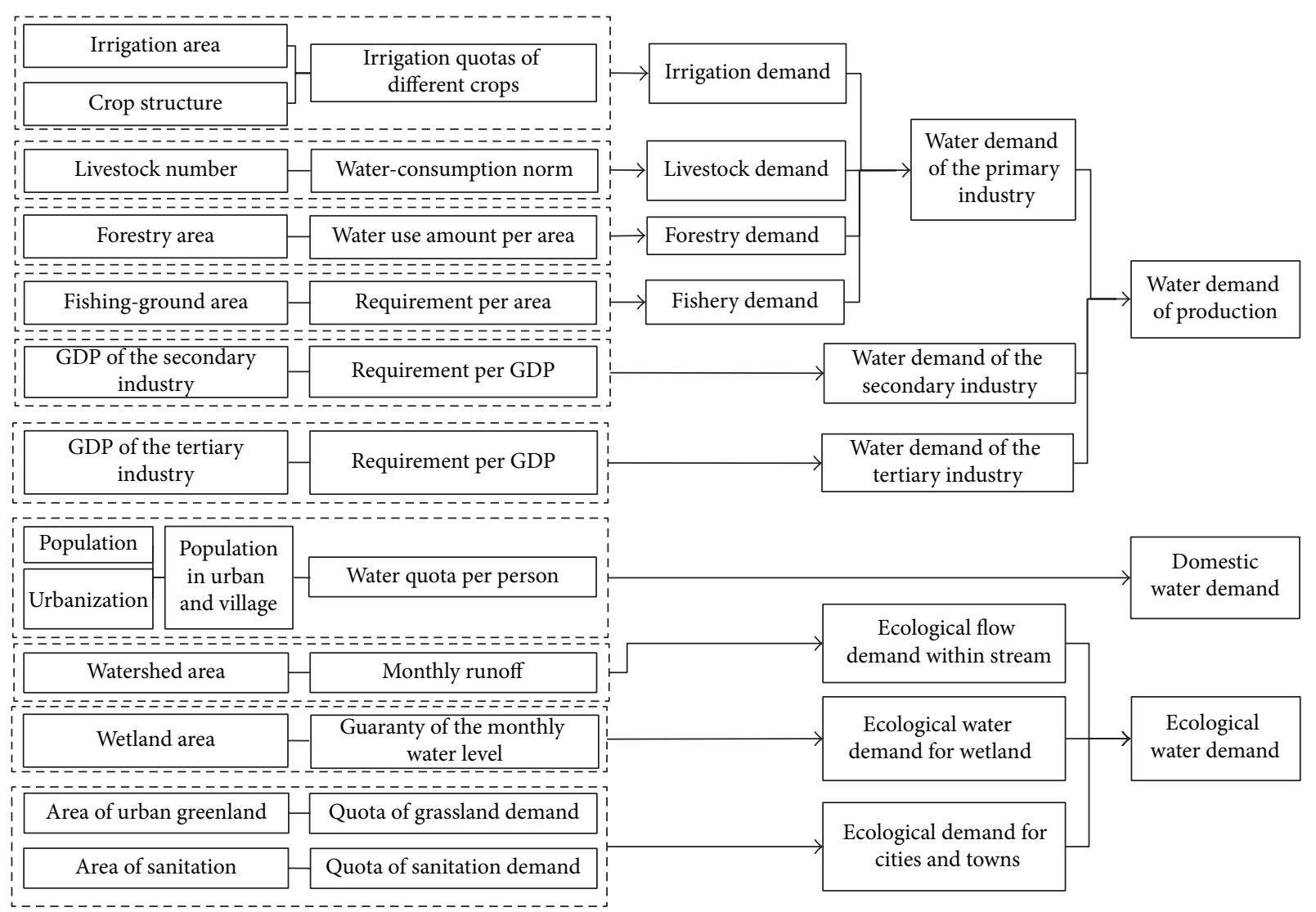

Figure 2: Technical framework of water demand. Remark: the left is "scale" and the right "quota" in the box with dotted line.

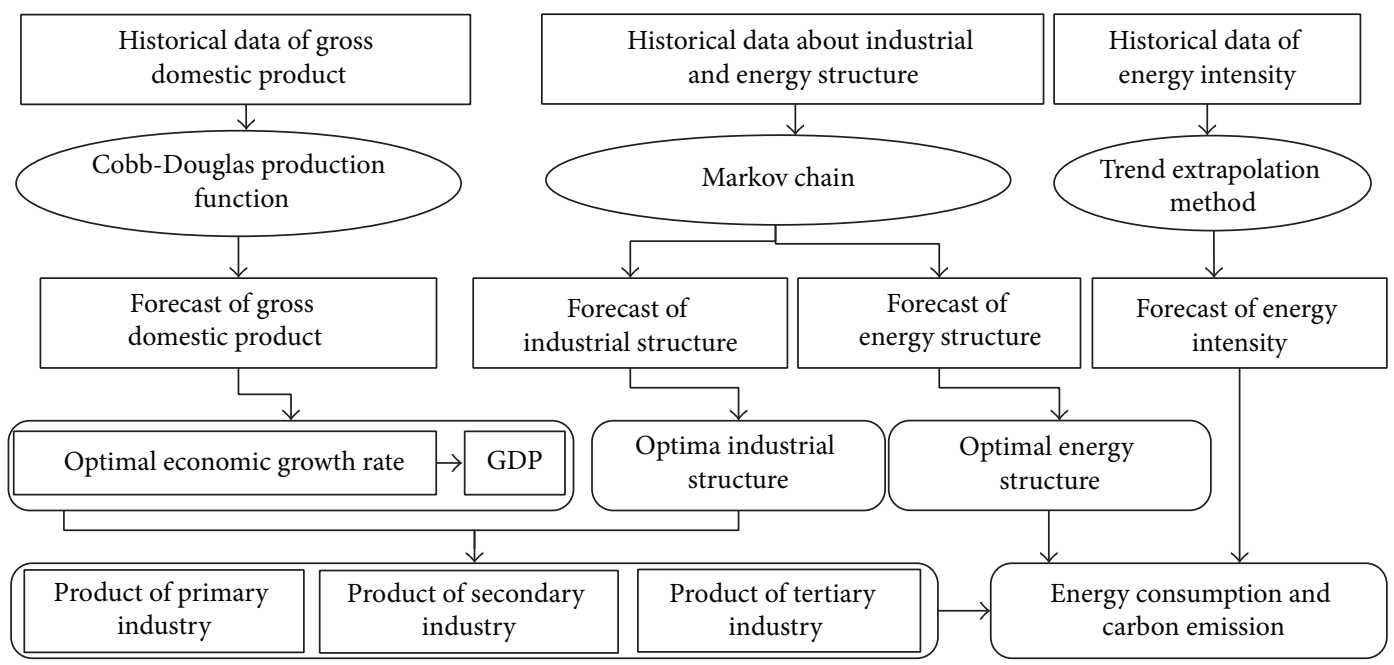

FIGURE 3: Method of forecasting GDP and carbon emission with the low-carbon mode.

which had the lowest total energy consumption. Optimal industrial structure and water use one were derived with Markov chain. The product of primary industry, secondary industry, and tertiary industry is, respectively, obtained based on forecasted results of optimal GDP and industrial structure. Then, the water demand scale of secondary industry and tertiary industry can be derived. Energy intensity was forecast with linear trend extrapolation method. Total energy consumption and carbon emissions were both derived based on these factors. Relationship of the above forecast methods is shown in Figure 3.

In respect of domestic water demand, population was forecast with the rate of natural population increase and urbanization level with linear trend extrapolation method. 
TABLE 4: Net irrigation quotas of different kinds of crops in different areas of basin; unit: $\mathrm{mm}$.

\begin{tabular}{lccccccc}
\hline Region & Wheat & Summer corn & Spring corn & Cotton & Fruit & Vegetable & Miscellaneous cereals \\
\hline Mountainous region & 218 & 56 & 99 & - & 225 & 306 & 28 \\
Hilly region & 218 & 113 & 98 & - & 225 & 303 & - \\
Plain region & 191 & 112 & - & 117 & 225 & 261 & - \\
\hline
\end{tabular}

In respect of water demand of natural ecosystem, ecological flow demand within stream was forecast based on the monthly runoff of major hydrostation and ecological water demand of wetland was forecast based on the monthly water level for different guaranties.

\subsection{Forecast of Population and Urbanization}

2.4.1. Population. The rate of natural population increase was considered in population forecast, while mechanical growth rate was not considered in this paper because of its uncertainty. Regional population was forecasted with the following formula:

$$
P=P_{0}(1+k)^{t},
$$

where $P$ and $P_{0}$ are the total population of planning level year and status year, respectively, $t$ is the number of planning level years, and $k$ is the natural increase rate during planning years.

2.4.2. Urbanization Level. Urbanization level is an important index weighing regional economic development. Trend extrapolation method was adopted to forecast it based on urbanization evolution during 2000-2010. Forecast methods of the two above factors are suitable for both extensive and low-carbon economic modes.

\subsection{Economic Index}

2.5.1. Economic Growth Rate. Economic growth rate of extensive economic mode was the same as that of 2010. In lowcarbon economic mode, Cobb-Douglas productive function model was adopted to forecast and optimize economic growth rate. Then, GDP was obtained.

This model relates optimal economic growth rate with low energy consumption, meeting the target of low-carbon mode. Moon and Sonn established Cobb-Douglas productive function model to research the relationship between economic growth and energy consumption [28]. It is as follows:

$$
Y(t)=\left(A_{0} e^{\nu t}\right)^{1 / \alpha} \tau(t)^{(1-\alpha) / \alpha}\left(\omega N_{0} e^{n t}\right)^{\gamma / \alpha} K(t), \quad 0<A_{0}<1 .
$$

Zhu et al. integrated employment rate and scientific technology factor into this function to improve it [29]. Then, improved optimal steady economic growth rate is as follows:

$$
g(t)=\left(n-\frac{\rho}{\delta}\right)+\frac{1}{\delta}(\varepsilon-\theta)\left(A_{0} e^{v t}\right)^{1 / \alpha} \tau(t)^{(1-\alpha)}\left(\omega(t) N_{0} e^{n t}\right)^{\gamma / \alpha},
$$

where $\tau(t)$ is energy intensity of the year $t$, which is ton of standard coal equivalent per 10 thousand RMB of GDP; $L(t)$ is the labor population of the year $t ; N_{0}$ is the total population of the initial year; $\omega(t)$ is the labor force participation rate, the same as employment rate; $n$ is the annual average rate of population growth; $\alpha$ is the capital output elastic coefficient; $\gamma$ is the labor output elastic coefficient; $v$ is the growth rate of total factor productivity; $\delta$ is the risk aversion coefficient; $\rho$ is the rate of time preference; $\varepsilon$ is error term; $\varepsilon=1-\delta$.

2.5.2. Industrial Structure. The ratio of the primary, secondary, and tertiary industry was forecast with Markov chain. Its result was used in low-carbon mode, while structure of 2010 was used in extensive mode.

\subsection{The Forecast of Production Water Demand}

2.6.1. The Primary Industry. Irrigation water demand is affected by precipitation, cultivated land, crop structure, irrigation area, and efficiency. In this paper, the point is economic development and agricultural planting so precipitation forecast is not considered temporally.

In the low-carbon economic mode, gross irrigation water requirement of the 2015 level year was forecast based on cultivated land area, crop structure, irrigation quotas of different crops, and water use efficiency of irrigation requested by Twelfth Five-Year Plan. The above factors related to irrigation were the same as those of 2010 except for cultivated land area with the extensive economic mode. However, in the lowcarbon mode, they were forecast with methods as follows.

Change rates of cultivated land area in 2015, 2020, and 2030 were forecast with trend extrapolation method on the basis of the status land area and the request of Twelfth FiveYear Plan. The results showed that change rates of Beijing municipality, Hebei province, and Shanxi province were $-4.8 \%,+1.4 \%$, and $+1.48 \%$, respectively.

Net irrigation quotas of different crops were referred to those set in Technique routine of high efficient water use of Hebei province and Local standard of water use of Hebei province (DB13), shown in Table 4. Irrigation quotas of Beijing Municipality and Shanxi province were similar as those of Hebei province because data collection was too difficult.

Water efficiency of irrigation of Beijing municipality is required to reach up 53\% and of Hebei province 74\% in 2015. There is no request for Shanxi province.

Water requirement of livestock was forecast based on livestock number and water consumption norm. In lowcarbon economic mode, daily water requirements of large 
TABLE 5: Forecast result of livestock amount for the whole basin; unit: 10 thousand.

\begin{tabular}{cccc}
\hline Year & Large livestock & Small livestock & Poultry \\
\hline 2015 & 76 & 591 & 5964 \\
2020 & 63 & 557 & 4369 \\
2030 & 77 & 599 & 6180 \\
\hline
\end{tabular}

livestock, small livestock, and poultry were $0.1 \mathrm{~m}^{3}, 0.025 \mathrm{~m}^{3}$, and $0.001 \mathrm{~m}^{3}$, respectively, according to local standard of water use of Hebei province (DB13). In extensive economic mode, this quota was the same as that of 2010. Amount of livestock was forecast with trend extrapolation method using historical data during 2000-2010, shown in Table 5. It is improved according to the requirements in the Twelfth FiveYear Plan. The result was used in two economic modes.

The result showed that the amount of livestock would be controlled in 2015 but would increase in 2030 due to scientific cultivation technology and people's diet. Forestry water demand was forecast based on the area and water use amount per area. Gross demand of forestry was derived with efficiency of water supply system. Growth rate of forestry area of Beijing municipality, Hebei province, and Shanxi province would be $8 \%, 1 \%$, and $0.5 \%$, respectively, according to the demand of the Twelfth Five-Year Plan. As a result, the area of Baiyangdian basin would be 55457 ha, 58177 ha, and 68427 ha in 2015,2020 , and 2030. The data is for both extensive and low-carbon economic modes.

Fishery demand was forecasted based on the area of fishing ground and water requirement per hectare. Because of the shortage of historical data of water use amount per fishingground area in Beijing municipality and Shanxi province, their quotas were forecasted with trend extrapolation method on the basis of historical sequence in Hebei province during 2000-2010. Gross quota of the whole basin would be 10.7 thousand $\mathrm{m}^{3}, 11.4$ thousand $\mathrm{m}^{3}$, and 9.2 thousand $\mathrm{m}^{3}$ per hectare in 2015, 2020, and 2030, respectively. With trend extrapolation method based on historical sequence during $2000-2010$, the area of fishing ground would be 5115.6 ha, 5112.6 ha, and 5106.7 ha in 2015,2020 , and 2030 , respectively.

In view of the two parameters mentioned above and efficiency of water supply system, gross water demand of fishery was obtained. In the extensive mode, efficiency of water supply system was the same as that of 2010; in the lowcarbon mode, it was set according to the request of Twelfth Five-Year Plan.

2.6.2. The Secondary and Tertiary Industry. Water demand of the secondary and tertiary industry was forecasted based on GDP, status and planning industry quota, efficiency of water supply system, and utilization ratio of recycled water.

GDP of the secondary and tertiary industry was forecasted based on industrial structure and optimal economic growth rate, which is shown in Table 6.

Water consumption of the whole basin was $22.8 \mathrm{~m}^{3}$ per 10 thousand GDP in 2010, which was adopted in the extensive mode. According to Twelfth Five-Year Plan, this index of Beijing municipality and Shanxi province would decrease by
TABLE 6: GDP of the secondary and tertiary industry for the lowcarbon mode; unit: billion RMB.

\begin{tabular}{lccc}
\hline Type & 2015 & 2020 & 2030 \\
\hline The secondary industry & 301.87 & 428.54 & 751.89 \\
The tertiary industry & 230.09 & 335.95 & 612.97 \\
\hline
\end{tabular}

TABLE 7: Estimation of key parameters.

\begin{tabular}{lccc}
\hline Parameter & Value & $t$-test value & Significance level \\
\hline$A_{0}$ & 1.666 & 4.495 & 0.002 \\
$v$ & 0.009 & 2.582 & 0.033 \\
$\alpha$ & 0.487 & 6.015 & 0.000 \\
$\gamma$ & 0.099 & 0.571 & 0.586 \\
\hline
\end{tabular}

$15 \%, 30 \%$, and $16.3 \%$, respectively, so that the whole basin would decrease by $25 \%$. It was adopted in the low-carbon mode.

The rate of treated sewage and reclaimed wastewater would increase to $85 \%$ and $15 \%$ according to Twelfth FiveYear Plan of National Municipal Wastewater Treatment and Reclaimed Wastewater Facility Construction.

2.7. Domestic Water Demand. Domestic water demand was forecasted through multiplying population by water quota per person based on population, urbanization level, the quota of domestic water use, and efficiency of water supply system. The last parameter was the same as that from Twelfth FiveYear Plan for the low-carbon mode, while it was the same as status data of 2010 in the extensive mode.

Natural population growth rates of Beijing municipality, Hebei province, and Shanxi province should not be bigger than $7.2 \%$, $7.13 \%$, and $6.5 \%$, which were specified by Twelfth Five-Year Plan. According to forecast result of natural growth rate, population of the whole basin would be 14.79 million, 14.91 million, and 15.01 million in 2015, 2020, and 2030.

Results showed that urbanization level would rise up to $55.13 \%, 59.72 \%$, and $63.59 \%$ in 2015,2020 , and 2030 . Net quota of domestic water use for each people was forecast with trend extrapolation method on the basis of historical sequence of domestic water use and population during 2001-2010. Net quota of cities would be $54.4 \mathrm{~L} / \mathrm{d}, 49.2 \mathrm{~L} / \mathrm{d}$, and $46.8 \mathrm{~L} / \mathrm{d}$, while net rural quota would be $56.6 \mathrm{~L} / \mathrm{d}, 57.5 \mathrm{~L} / \mathrm{d}$, and $57.9 \mathrm{~L} / \mathrm{d}$.

2.8. Ecological Water Demand. Ecological water users include natural system and artificial system. The former one involves ecological flow requirement within the stream and wetland ecological water demand and the latter one involves water demand in green land of cities and towns. This part was also considered in the low-carbon mode.

2.8.1. Ecological Flow Demand within Stream. Considering both calculation requirement and present data, ecological flow demand within stream equaled the maximum value between $90 \%$ of flow frequency and average runoff of the 
TABLE 8: Optimal economic growth rate and energy consumption with different economic modes.

\begin{tabular}{ccccc}
\hline \multirow{2}{*}{ Year } & \multicolumn{2}{c}{ Extensive mode } & \multicolumn{2}{c}{ Low-carbon mode } \\
& Energy consumption (Mtce) & Economic growth rate (\%) & Energy consumption (Mtce) & Optimal economic growth rate (\%) \\
\hline 2015 & 99.1 & 12.3 & 74.6 & 8.2 \\
2020 & 176.99 & 12.3 & 91.6 & 6.9 \\
2030 & 564.58 & 12.3 & 119.9 & 5.2 \\
\hline
\end{tabular}

driest period. Ecological flow demand within stream of lackdata watershed was converted with area compared to the one having data. That was because hydrological stations with observation data were all in the upstream and there was no main stream in Baiyangdian basin.

\subsubsection{Ecological Water Demand for Wetland. Ecological} water demand for Baiyangdian wetland was forecasted to protect the wetland and brought into full play its ecoenvironmental and social-economic effect. Considering factors such as protection targets, protection scale, constituents of ecosystem, and trophic structure of Baiyangdian wetland, ecological water demand for wetland was assessed under different schemes.

2.8.3. Ecological Demand for Cities and Towns. This part involves grassland and sanitation. Relevant quota was set according to Twelfth Five-Year Plan of Water Resource. Based on status water use of Haihe River basin and Integrated Plan of Water Resource in Hebei, quotas of grassland and sanitation are $3000 \mathrm{~m}^{3}$ and $900 \mathrm{~m}^{3}$ per hectare. The ratio of green land in Beijing municipality, Hebei province, and Shanxi province is requested to be $57 \%, 35 \%$, and $36 \%$ in 2015 , respectively.

\section{Results and Discussion}

3.1. Population and Urbanization Level. Results showed that the population of Baiyangdian basin would be 14.79, 14.91, and 1.51 million persons and urbanization level would be $55.1 \%$, $59.7 \%$, and $63.6 \%$ in 2015,2020 , and 2030 .

3.2. Economic Growth and Energy Consumption. Linear regression analysis was used to derive key parameters of Cobb-Douglas productive function model of Baiyangdian basin with SPSS, shown in Table 7.

Results demonstrated that equation fitting rate $R^{2}$ was equal to 0.995 and significance levels of $A_{0}, v$, and $\alpha$ were under that of $5 \%$ except $\gamma$ which was not significantly related to economic growth rate. As a result, the labor force participation rate was not involved in this model and the function is changed as follows:

$$
g(t)=-\frac{1}{\delta}\left[\rho-(\varepsilon-\theta \tau(t))\left(A_{0} e^{v t}\right)^{1 / \alpha} \tau(t)^{(1-\alpha)}\right] .
$$

That may be caused by short sequence of historical data. Penetration rate of carbon emission reduction and energy saving technology can be integrated into the model if possible in the future.
TABLE 9: Water demand of the primary, secondary, and tertiary industry at the different planning levels $\left(0.1\right.$ billion $\left.\mathrm{m}^{3}\right)$.

\begin{tabular}{lcccccc}
\hline \multirow{2}{*}{ Type } & \multicolumn{3}{c}{ Status level } & \multicolumn{3}{c}{ Planning level } \\
& 2015 & 2020 & 2030 & 2015 & 2020 & 2030 \\
\hline Agriculture & 32.12 & 32.72 & 33.05 & 19.81 & 20.1 & 20.39 \\
Forestry & 2.04 & 2.52 & 3.85 & 1.77 & 2.18 & 3.33 \\
Livestock & 1.62 & 1.4 & 1.65 & 0.9 & 0.78 & 0.91 \\
Fishery & 0.55 & 0.58 & 0.47 & 0.47 & 0.51 & 0.41 \\
Primary industry & 36.32 & 37.22 & 39.03 & 22.95 & 23.56 & 25.05 \\
Secondary industry & 6.89 & 9.78 & 17.20 & 2.98 & 4.23 & 7.42 \\
Tertiary industry & 2.45 & 3.58 & 6.54 & 1.06 & 1.55 & 2.82 \\
\hline
\end{tabular}

Optimized economic growth rate simulated from the function model should conform to the actual growth rate so this could be a constraint condition for the regulation of $\delta$ and $\rho$. Thus we got $\delta=8.903$ and $\rho=-0.829$.

Based on the estimation of the above parameters, optimal economic growth rate and energy consumption were derived for the low-carbon economic mode, shown in Table 8.

3.3. Water Demand of Production. Water demand of the primary industry accounts for more than $60 \%$ of the total demand of production. However, rapid development of the secondary and tertiary industry leads to the low weight of the primary industry. Results showed that no matter whether the water use was maintained in the current situation or according to the Twelfth Five-Year Plan, gross water demand of the primary industry would decrease, while the secondary and tertiary industry would increase, which is shown in Table 9.

3.4. Domestic Water Demand. According to the result, with the increase of urbanization, water demand of cities would have an increasing trend and that of villages would have a decreasing trend, which is shown in Table 10. Due to the increasing water efficiency of cities and decreasing quota of each person, the increase rate of domestic water demand would slow down in the future.

\subsection{Ecological Water Demand}

3.5.1. Ecological Water Demand within Stream. Monthly water demand within stream was derived with the principle of no river blanking based on natural monthly data of Wang Kuai, Xidayang, Zijinguan, Angezhuang, Zhang Fang, and Hengshanling hydrological station. Results are shown in Table 11. 
TABLE 10: Domestic water demand of the basin in the different planning level year; unit: 0.1 billion $\mathrm{m}^{3}$.

\begin{tabular}{ccccccccccccc}
\hline & \multicolumn{2}{c}{ Status } & \multicolumn{2}{c}{2030} & \multicolumn{2}{c}{ Plan } \\
\hline \multicolumn{2}{c}{2015} & \multicolumn{2}{c}{2020} & \multicolumn{2}{c}{2015} & \multicolumn{2}{c}{2020} & \\
City & Village & City & Village & City & Village & City & Village & City & Village & City & Village \\
2.27 & 2.37 & 2.40 & 2.16 & 2.54 & 1.80 & 1.97 & 2.05 & 2.08 & 1.87 & 2.20 & 1.56 \\
\hline
\end{tabular}

TABLE 11: Monthly water demand of typical hydrological station in the basin; unit: 10 thousand $\mathrm{m}^{3}$.

\begin{tabular}{lcccccc}
\hline Hydrological station & Wang Kuai & Xidayang & Zijinguan & Angezhuang & Zhang Fang & Hengshanling \\
\hline River name & Zhulong River & Ci River & Juma River & Zhongyishui River & Juma River & Ci River \\
Monthly runoff of 90\% frequency & 0 & 419 & 589 & 0 & 718 & 0.00 \\
Average annual value & 530 & 1019 & 935 & 20 & 1544 & 47 \\
Monthly water demand & 530 & 419 & 589 & 20 & 718 & 47 \\
\hline
\end{tabular}

TABLE 12: Annual ecological water demand of different rivers in the basin ( 0.1 billion $\left.\mathrm{m}^{3}\right)$.

\begin{tabular}{|c|c|c|c|c|c|c|c|}
\hline River & Juma River & Zhongyishui River & $\begin{array}{l}\text { Pu River, Cao River, } \\
\text { and Qingshui River }\end{array}$ & Tang River & Sha River & Ci River & Whole basin \\
\hline $\begin{array}{l}\text { Amount of ecological water } \\
\text { demand within stream }\end{array}$ & 0.86 & 0.02 & 0.06 & 0.50 & 0.64 & 0.06 & 2.14 \\
\hline
\end{tabular}

Both Zi-jinguan and Zhang-fang hydrological station are in the Jvma river. As a result, their maximum was chosen as the monthly water demand of the river. There is a lack of observation data of $\mathrm{Pu}$ River, Cao River, and Qingshui River. Their annual water demand was converted through comparing area of them to that of Zhong-yishui river. Annual ecological water demand of main rivers in the upstream was derived and that of the whole basin was 0.214 billion $\mathrm{m}^{3}$, shown in Table 12 . It would be 0.136 billion $\mathrm{m}^{3}$ only if the monthly runoff of $90 \%$ frequency was considered.

Monthly forecast of ecological water demand within stream was not completed because of incomplete data of precipitation, runoff and evaporation, and no match on spatial and temporal scale. If enough regional data is got, dynamic analysis will be done.

3.5.2. Ecological Water Demand of Baiyangdian Wetland. $65 \%$ and $75 \%$ guaranties of the monthly water level are suitable for bulrush production, fishery production, diversion and storage of floods, and keeping the habit of target species, the great reed warbler, as discussed by Zhao [30]. Corresponding annual water demand of wetland is 0.472 and 0.389 billion $\mathrm{m}^{3}$. The latter was more suitable for this paper considering the cost of water supply.

3.5.3. Ecological Demand for Cities and Towns. Forecast results of ecological demand for cities and towns are shown in Table 13.

3.6. Total Water Demand. Total water demand was derived based on the above results and it was demonstrated that it would increase by $1.269,1.529$, and 2.163 billion $\mathrm{m}^{3}$ in 2015 ,
TABLE 13: Ecological demand for cities and towns in the basin (10 thousand $\mathrm{m}^{3}$ ).

\begin{tabular}{lccccc}
\hline \multicolumn{3}{c}{ Status } & & \multicolumn{3}{c}{ Plan } \\
\hline 2015 & 2020 & 2030 & 2015 & 2020 & 2030 \\
15040.77 & 17883.16 & 25885.25 & 12533.98 & 14902.63 & 21571.04 \\
\hline
\end{tabular}

2020, and 2030 with the extensive economic mode compared to that of low-carbon mode, shown in Table 14.

\section{Conclusions}

Taking Baiyangdian basin as the example, this paper constructed the extensive and low-carbon economic mode and quantitatively analyzed their effects on regional water demand. Results showed that total water demand with the extensive mode would increase by 1.27 billion $\mathrm{m}^{3}, 1.53$ billion $\mathrm{m}^{3}$, and 2.16 billion $\mathrm{m}^{3}$ in 2015,2020 , and 2030, respectively, compared with that of low-carbon economic mode.

Low-carbon economic mode has optimal economic growth rate. It can not only be in accordance with the target of carbon emission reduction, but also control productive and domestic water demand and meet the requirement of ecological system. Results of Baiyangdian basin can provide data for water resource plan, target of ecoenvironmental conservancy plan, and water resource allocation of intake area of south-to-north project.

Some aspects of this research have to be improved, including forecast of economic growth rate, irrigation, and ecological water demand within stream if enough data is collected. 
TABLE 14: Total water demand of the basin with the extensive and low-carbon economic mode $\left(0.1\right.$ billion $\left.\mathrm{m}^{3}\right)$.

\begin{tabular}{lcccccccc}
\hline Year & \multicolumn{2}{c}{ Productive water demand } & \multicolumn{2}{c}{ Domestic water demand } & \multicolumn{2}{c}{ Ecological water demand } & \multicolumn{2}{c}{ Total water demand } \\
& Extensive & Low-carbon & Extensive & Low-carbon & Extensive & Low-carbon & Extensive & Low-carbon \\
\hline 2015 & 45.66 & 26.98 & 4.64 & 4.02 & 1.50 & 8.11 & 51.80 & 39.11 \\
2020 & 50.58 & 29.34 & 4.56 & 3.95 & 1.79 & 8.35 & 56.93 & 41.64 \\
2030 & 62.77 & 35.29 & 4.34 & 3.76 & 2.59 & 9.02 & 69.70 & 48.07 \\
\hline
\end{tabular}

\section{Conflict of Interests}

The authors declare that there is no conflict of interests regarding the publication of this paper.

\section{Acknowledgments}

The paper was supported by the Project of Influence Mechanism of Climate Change on Water Cycle in Huang-HuaiHai River Area and Water Resources Security Evaluation (2010CB951102) of the National Program on Key Basic Research Project (973 Program) and the General Program of the National Natural Science Foundation of China (Grant no. 51279207).

\section{References}

[1] H. Wang, D.-H. Yan, Y.-W. Jia, D.-L. Hu, and L.-H. Wang, "Subject system of modern hydrology and water resources and research frontiers and hot issues," Advances in Water Science, vol. 21, no. 4, pp. 479-489, 2010.

[2] M. Salman and W. Mualla, "Water demand management in Syria: centralized and decentralized views," Water Policy, vol. 10, no. 6, pp. 549-562, 2008.

[3] R. M. Saleth, "Water scarcity and climatic change in India: the need for water demand and supply management," Hydrological Sciences Journal, vol. 56, no. 4, pp. 671-686, 2011.

[4] D.-H. Yan, T.-L. Qin, P. Zhang, and Z.-Q. Xing, "Study on water resources rational deployment framework based on the lowcarbon development mode," Journal of Hydraulic Engineering, vol. 41, no. 8, pp. 970-976, 2010.

[5] D.-H. Yan, T.-L. Qin, W.-H. Xiao, and D.-X. Li, "Study on the model of water resources rational deployment for the lowcarbon development mode," Journal of Hydraulic Engineering, vol. 43, no. 5, pp. 586-593, 2012.

[6] X.-R. Huang, X.-H. Zhang, Y.-S. Pei, and C. Liang, "Rational deployment of water resources in Ningxia Autonomous Region based on rationalization of macroeconomic structure," Journal of Hydraulic Engineering, vol. 37, no. 3, pp. 371-375, 2006.

[7] D.-H. Yan, H. Wang, S.-Y. Yang, and Z. Huo, "Ecology-oriented reasonable deployment of water resources and giving priority to protection of wetland," Journal of Hydraulic Engineering, vol. 39, no. 10, pp. 1241-1247, 2008.

[8] R. G. Gistau, "Dem and forecasting in water supply systems," in Water Supply Systems: State of the Art and Future Trends, E. Cabrera and F. Martinez, Eds., pp. 56-64, Computational Mechanics Publications, Southampton, UK, 1993.

[9] S. Leonid and F. Mordechai, "Forecasting hourly water demand of pattern approach," Water Supply, vol. 4, no. 5, pp. 168-172, 2003.
[10] S. L. Zhou, T. A. McMahon, A. Walton, and J. Lewis, "Forecasting daily urban water demand: a case study of Melbourne," Journal of Hydrology, vol. 236, no. 3-4, pp. 153-164, 2000.

[11] L. W. Mays, "Water demand forecasting," in Hydrosystem Engineering and Management, pp. 24-32, 1992.

[12] J. F. Adamowski, "Peak daily water demand forecast modeling using artificial neural networks," Journal of Water Resources Planning and Management, vol. 134, no. 2, pp. 119-128, 2008.

[13] A. Yasar, M. Bilgili, and E. Simsek, "Water demand forecasting based on stepwise multiple nonlinear regression analysis," Arabian Journal for Science \& Engineering, vol. 37, no. 8, pp. 2333-2341, 2012.

[14] P. A. Zhong, X. Y. Chen, and K. Chen, "Synthetic prediction method for industrial water demand," Journal of Hohai University, vol. 29, no. 4, pp. 67-71, 2001.

[15] Y. J. Zhang, Q. S. Liu, C. M. Feng et al., "Linear multiple regression for domestic water demand forecasting in Beijing," Water \& Wastewater Engineering, vol. 29, no. 4, pp. 26-28, 2003.

[16] M. Lv, H. B. Zhao, H. W. Li et al., "Combined practical dynamic modeling prediction hourly water consumption," Water \& Wastewater Engineering, vol. 14, no. 1, pp. 9-11, 1998.

[17] Z. Ling, C. Xiao-Hong, and L. Qing-Er, "PP model of water demand prediction based on IEA," Journal of Irrigation and Drainage, vol. 27, no. 1, pp. 73-76, 2008.

[18] R. G. Gistau, "Demand forecasting in water supply systems," in Water Supply Systems: State of the Art and Future Trends, E. Cabrera and F. Martinez, Eds., pp. 56-64, Computational Mechanics Publications, Southampton, UK, 1993.

[19] A. Ibrahim, A. Abdelhamid, K. Yasir, and E. Ali, "A probabilistic forecast of water demand for a tourist and desalination dependent city: case of Mecca, Saudi Arabia," Desalination, vol. 294, pp. 53-59, 2012.

[20] C. Qi and N.-B. Chang, "System dynamics modeling for municipal water demand estimation in an urban region under uncertain economic impacts," Journal of Environmental Management, vol. 92, no. 6, pp. 1628-1641, 2011.

[21] M. M. Mohamed and A. Al-Mualla, "Water demand forecasting in Umm Al-Quwain using the constant rate model," Desalination, vol. 259, no. 1-3, pp. 161-168, 2010.

[22] M. Lv, H. B. Zhao, L. Hongwei et al., "Combined practical dynamic modelling predicting hourly water consumption," China Water Supply and Drainage, vol. 14, no. 1, pp. 9-11, 1998.

[23] C. C. Zhang, Y. B. Cui, and C. H. Hu, "Study on water demand forecast methods," Meteorological and Environmental Sciences, vol. 32, no. 1, pp. 1-4, 2009.

[24] W. Li and Z. Huicheng, "Urban water demand forecasting based on HP filter and fuzzy neural network," Journal of Hydroinformatics, vol. 12, no. 2, pp. 172-184, 2010.

[25] D. B. Bai and Z. P. Ning, "Discussion on causes of dry lake of Baiyangdian wetland," China Flood and Drought Control, vol. 2, pp. 46-62, 2007. 
[26] T. L. Qin, D. H. Yan, H. Wang et al., "Rational allocation of water resource towards the low-carbon development mode in Baiyangdian Basin," in Proceedings of the IAHR World Congress, 2013.

[27] J. Wang and Z. X. Xu, "Long-term trend and the sustainability of air temperature and precipitation in the Baiyangdian Basin," Resources Science, vol. 31, no. 9, pp. 1498-1505, 2009.

[28] Y.-S. Moon and Y.-H. Sonn, "Productive energy consumption and economic growth: an endogenous growth model and its empirical application," Resource and Energy Economics, vol. 18, no. 2, pp. 189-200, 1996.

[29] Y. Zhu, Z. Wang, L. Pang, L. Wang, and X. Zou, "Simulation on China's economy and prediction on energy consumption and carbon emission under optimal growth path," Acta Geographica Sinica, vol. 64, no. 8, pp. 935-944, 2009.

[30] Z. X. Zhao, Coupling Mechanism of Eco-Hydrological Processes and Integrated Regulation in Baiyangdian Wetland, Tianjin University, 2012. 


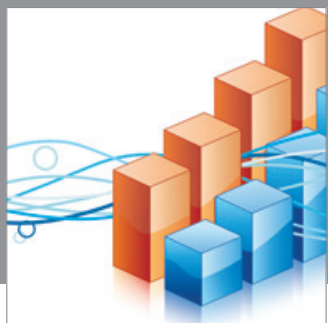

Advances in

Operations Research

mansans

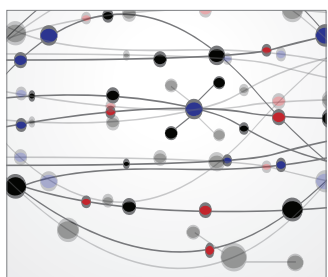

The Scientific World Journal
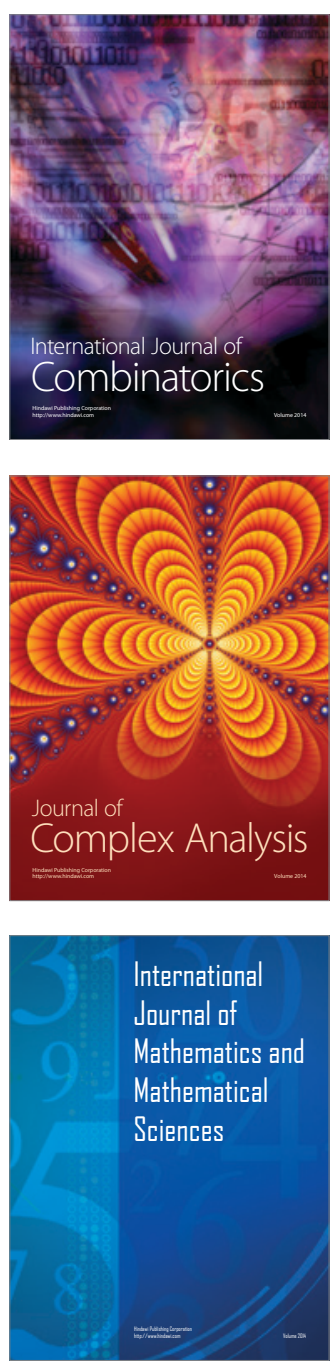
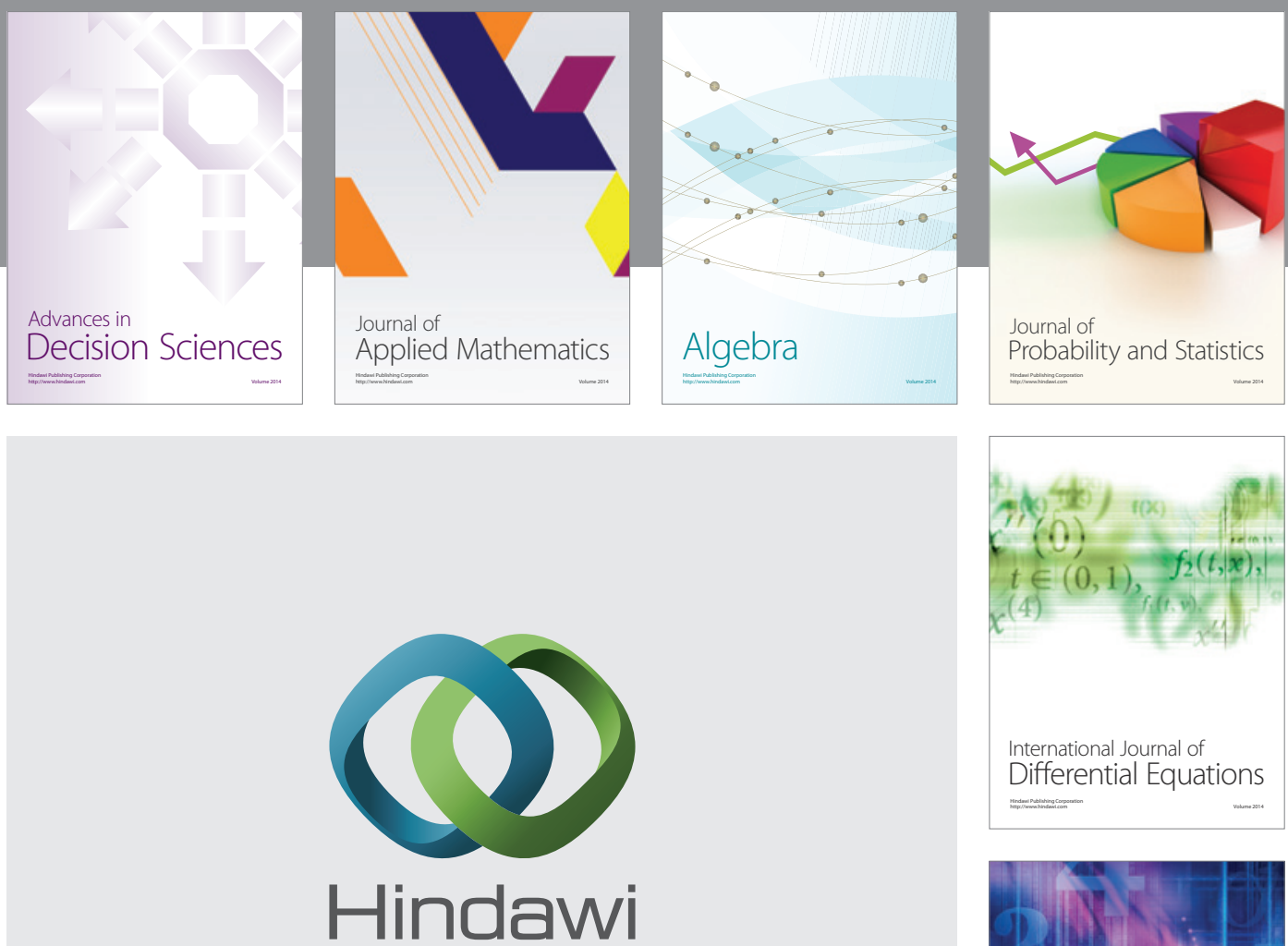

Submit your manuscripts at http://www.hindawi.com
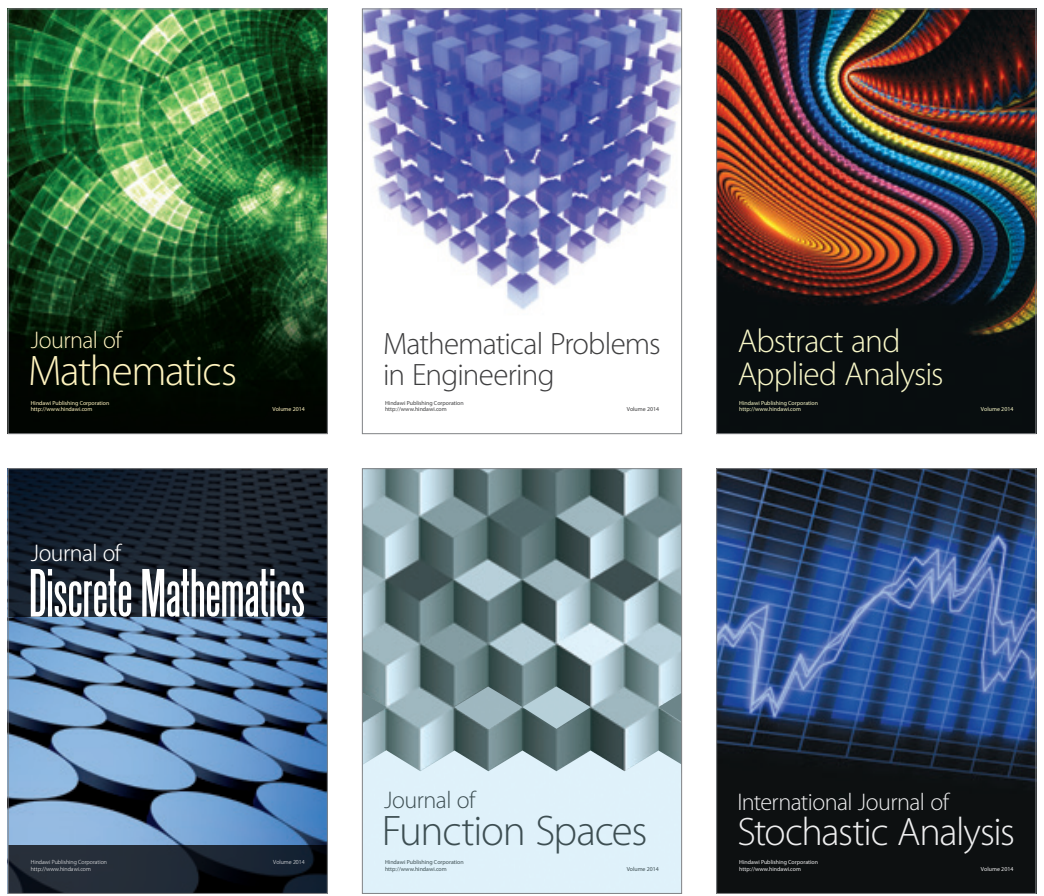

Journal of

Function Spaces

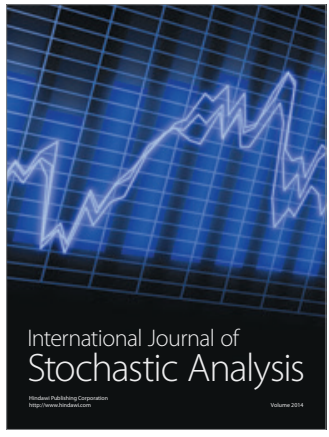

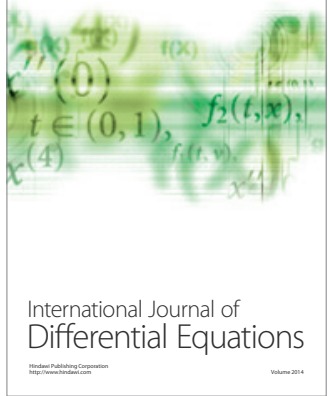
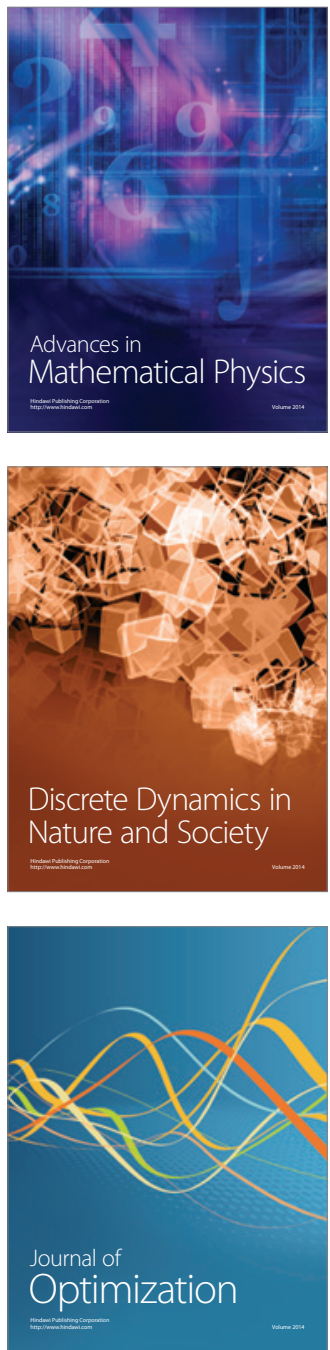